\title{
PROTECTIVE-ADAPTIVE REACTION OF GENUS SUAEDA PLANTS IN NORTH-WESTERN AZOV REGION OF UKRAINE
}

\author{
Pyurko O. E., Pyurko V. E.
}

\section{INTRODUCTION}

Topic relevance. The problem of practical use of saline soils in agriculture is particularly relevant for areas of risky agriculture due to global climate aridization and significant expansion of arid and saline regions ${ }^{1}$. Nowadays, the issues of salt resistance of plants attract more and more attention of scientists around the world. The fact is that huge areas of the globe are characterized by varying degrees of salinity - about $25 \%$ of all the planet's soils $^{2}$. One-third of the world's irrigated land has already been changed to excess salt due to poor drainage ${ }^{3}$. One of the main reasons for salinization of agricultural land has become unusable over time ${ }^{4}$. The problem of salinity is extremely relevant for our country, since most of the irrigated land, especially in the South of Ukraine, is saline ${ }^{5}$. Secondary salinization of soils causes great damage to agriculture every year. The creation of rational agrotechnical and meliorative systems on saline soils can only be based on a deep understanding of their histological and physiological properties ${ }^{6}$.

The research purpose is to study the adaptations of plants of the genus Suaeda L. (Pall.) existence on saline soils in the conditions of the NorthWestern Azov region of Ukraine. Elucidation of physiological and quantitative-anatomical features will reveal the potential, protective and adaptive reactions, thanks to which the survival of plants in conditions of excessive salinization of the soil is carried out.

Research object - protective and adaptive features of evhalophytes (on the example of genus Suaeda L. plants) as an indicator of specific adaptations to salt stress.

\footnotetext{
${ }^{1}$ Войтюк Б.Ю. Рослинність засолених грунтів Північно-Західного Причорномор'я (сучасний стан, класифікація, напрямки трансформації, охорона). Київ : Фітосоціоцентр, 2005. 224 с.

Waisel Y. Biology of halophytes. New York-London : Acad. Press, 1972. P. 146-148.

2 Захаревич С.Ф. К методике описания эпидермиса листа. Вестник Ленин. Университета. 1954. № 4. C. $65-75$.

Yeo A.R. Molecular Biology of salt tolerance. Phisiol. Plantarum. 1983. V. 58. P. 214-220.

3 Лотова Л.И. Ботаника: Морфология и анатомия высших растений. Москва : КомКнига, 2007. $512 \mathrm{c}$.

Нечитайло В.А., Кучерява Л.Ф. Ботаніка. Вищі рослини. Київ : Фітосоціоцетр, 2005. 214 с.

${ }^{4}$ Мусієнко М.М. Фізіологія рослин. Київ : Либідь, 2005. 807 с.

Crawley M. Plant Ecology. Berlin : Blacwell Science, 2000. 717 p.

${ }^{5}$ Medvedev S.S. Plant physiology. Moscow : St-Petersburg, 2015. 506 p.

${ }^{6}$ Bartels D., Sunkar R. Drought and salt tolerance in plants. Critical Rev. Plant Sci. 2005. P. 24-36.

Larcher W. Physiological Plant Ecology. Berlin : Springer, 1995. 505 p. 
Research subject - salttolerance morpho-anatomical and ecologicalphysiological features of evhalophyte-Suaeda altissima L. and Suaeda miritima L.

\section{Materials and methods}

During the theoretical study of the problem, experimental research and experimental work applied theoretical analysis and generalization of scientific and methodological literature on morphology, anatomy and physiology of plants, periodical materials; experimental method; quantitative anatomical and physiological analysis; mathematical and statistical data processing.

Quantitative and anatomical studies were performed using generally accepted cytological methods ${ }^{7}$. The material was collected on the territory of the North-Western Azov region (s. Strogonovka, Mordvinivka). The comparative structural and functional characteristics of Suaeda altissima L. (Pall.) and Suaeda miritima L. plants grown on saline (up to 1.5\%) and nonsaline soil were used.

The concentration of cell juice was determined using the refractometric method, and catalase activity was determined using the gasometrical method ${ }^{8}$. The quantitative content of pigments was determined from alcohol and acetone extracts on KPC-3. The water content during daylight hours was determined by weather measurements using a device for determining the specific surface density of the leaf ${ }^{9}$. All data is processed statistically, the error of experiments does not exceed $5 \%$.

\section{Research result}

Suaeda altissima L. leaf is filamentous, covered with a single layer of epidermis, the main cells of the epidermis-round, polyhedral. Using the Zaharevich method ${ }^{10}$ when studying the main cells of the leaf cover tissue, we identified two types of cells that differ in size and projection: type I-the projection of cells is 5-6 angular, the outline of cells is straight, the corners are pointed and blunt, the number of cells per $1 \mathrm{~mm}^{2}-150$ pieces, the cell size

\footnotetext{
${ }^{7}$ Казаков С.О., Пюрко О.С., Христова Т.С. Методичні аспекти фізіологічного моніторингу рослин Приазов’я. Питання біоіндикації та екології. Запоріжжя, 2002. С. 141-152.

Казаков Є.О. Методологічні основи постановки експерименту з фізіології рослин : монографія. Київ : Фітосоціоцентр, 2000. 285 с.

Waisel Y. Biology of halophytes. New York-London : Acad. Press, 1972. P. 146-148.

${ }^{8}$ Казаков С.О., Пюрко О.С., Христова Т.С. Методичні аспекти фізіологічного моніторингу рослин Приазов'я. Питання біоіндикації та екології. Запоріжжя, 2002. C. 141-152.

Казаков С.О. Методологічні основи постановки експерименту з фізіології рослин : монографія. Київ : Фітосоціоцентр, 2000. 285 с.

${ }^{9}$ Казаков С.О., Пюрко О.С., Христова Т.С. Методичні аспекти фізіологічного моніторингу рослин Приазов’я. Питання біоіндикації та екології. Запоріжжя, 2002. С. 141-152.

Казаков С.О. Методологічні основи постановки експерименту з фізіології рослин : монографія. Київ : Фітосоціоцентр, 2000. 285 с.

10 Захаревич С.Ф. К методике описания эпидермиса листа. Вестник Ленин. Университета. 1954. № 4. C. $65-75$.
} 
along the long axis is $720 \mu \mathrm{m}, \mathrm{S}=4800 \mathrm{mkm}^{2}$; type II - projection of cells 5-6 angular, cell outlines straight, angles pointed and blunt, the number of cells per $1 \mathrm{~mm}^{2}-240$ pieces, the cell size along the long axis is 380 microns, $\mathrm{S}=1200 \mathrm{mkm}^{2}$. There are anomalies of stomatal complexes: type I - two stomata are in the same polygonal the cell shape cells straight, angles acuminate and obtuse; II type - stomata surrounded by two cells on one side of the 6-corner cell, and the other-5-corner cell, and cells with a rectilinear shape, with sharp angles and obtuse angles; type III - a of the stoma is accompanied by two cells, one of which is much larger than the other; IV type - stomata surrounded by a pair of epidermal cells, the common walls of which are at right angles to the trailing cells. Type of stomatal apparatus is anomosity. According to the authors prodigal abnormal complexes occur under the influence of stress. On average, the short axis of the polygonal cell is 240 microns, the long axis-300 microns. The number of stomata is 40 pieces $/ \mathrm{mm}^{2}$.

The leaf of Suaeda altissima L. has the same type of structure (Fig. 1): the leaf is covered with a layer of cuticle, which is $0.9 \%$ of the total thickness. The epidermal cells are closely adjacent to each other and make up 3.6\% of the entire thickness of the leaf. The inner structure of the leaf is represented by mesophyll $(95,5 \%)$. Mesophyll is differentiated into photosynthetic parenchyma $(65,5 \%)$ and water-bearing $(30 \%)$. The water-bearing cells are surrounded by lining cells. In the center of the leaf are the leading bundles in a circle, which are directly adjacent to the cells of the lining. The leading beam is represented by xylem and phloem, and is 10,9\% of the entire thickness of the cut. Salinity acts in a peculiar way on the constituent cells of the epidermis, causing an increase in the size of the main cells by $12-15 \%$, and the closing ones - by $5-7 \%$.

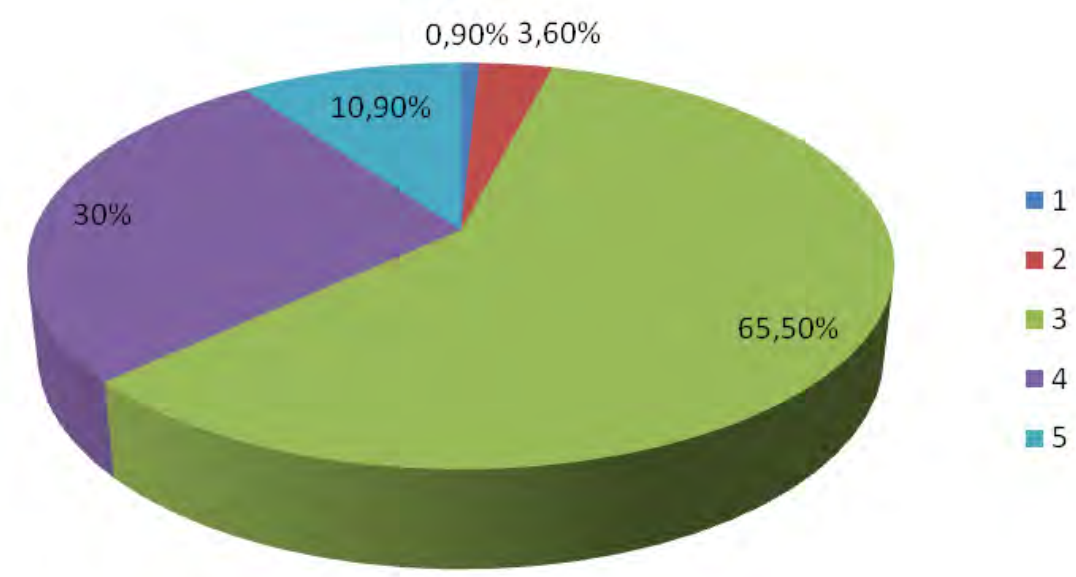

Fig. 1. Histological structure of the leaf of Suaeda altissima L.: 1-cuticle, 2-epidermis, 3-parenchyma, 4-water-bearing parenchyma, 5-SVP 
For a detailed study of Suaeda altissima L. cross-sections were made in such parts of the stem in the upper part, in the middle part and tender. Our research has shown that the stem of Suaeda altissima L. the upper part consists of the following parts (Fig. 2): bark (33,5\%), cambium (1,6\%), wood $(43,7 \%)$, and core $(21,2 \%)$. The upper part of the stem differs in size from the middle and lower part of the stem. The bark of the stem is represented by the following tissues: the primary covering tissue - the epidermis consists of a single row of cells that are tightly adjacent to each other, and is $1,8 \%$ of the total thickness.

Next is the collenchyma, which provides support for the stem, forms separate continuous strands under the epidermis. In this plant, the collenchyme is angular, which is $10 \%$ of the total thickness. The last part of the bark is $18.8 \%$. This is a fairly large figure, because the parenchymal cells of the bark of this plant perform a water-saving function and have a fairly significant size: on average, the parenchyma of the bark is $16,4 \%$, behind the bark is a meristematic tissue-cambium $(1,6 \%)$. Then there is a layer of wood $(17,3 \%)$, represented by sclerenchyme $(4,3 \%)$ and vascular-fibrous bundles $(13 \%)$. Vascullar bundles are arranged in a sequence, forming a circle. SVP in the form of side, closed.

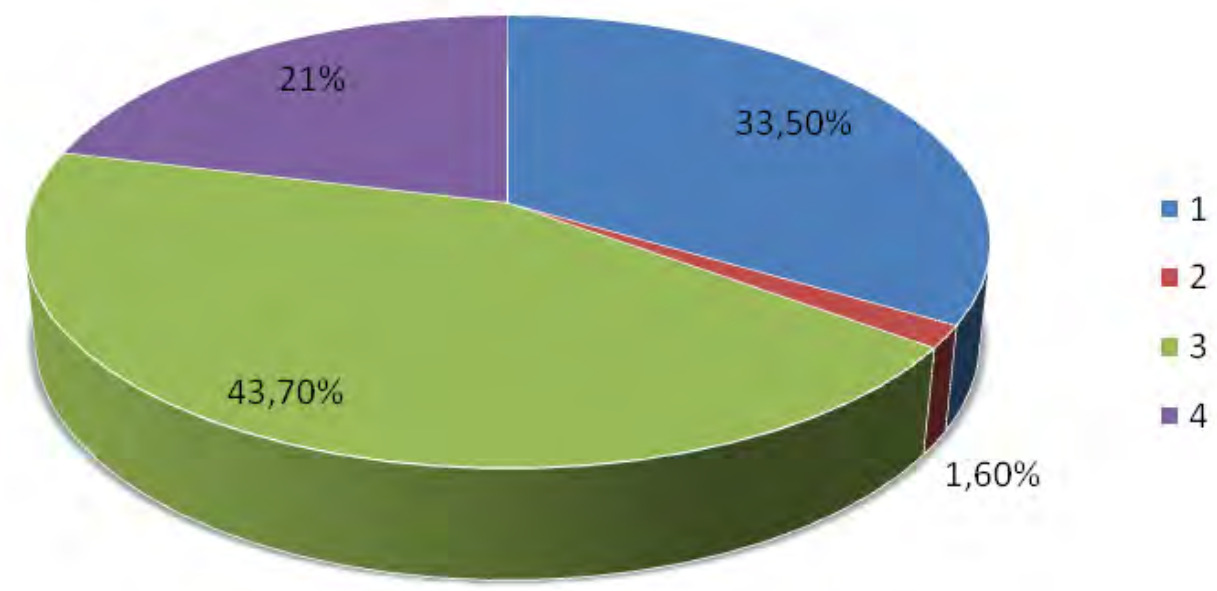

Fig. 2. Histological structure of the stem of Suaeda altissima $L$. : 1-bark, 2-cambium, 3-wood, 4-core

It should be noted that the SVP xylem is adjacent directly to the cells of the core, which performs a water-saving function. It was found that halophytes have water in the parenchymal cells in a bound state. When the temperature rises, the water passes into a free state and immediately, without any obstacles, enters the xylem vessels, along which it moves. Behind the wood is the core, which is represented by large water-saving cells of a regular round shape. The core presents: cells of I formation - they are very small and their 
sizes from the total slice is $1,4 \%$; the most common cells of II formation constituting $2,8 \%$ of total slice thickness; cells III formation are very large, they account for $5,8 \%$ of the total thickness.

The middle part of the stem consists of the same tissues as the upper part, only in different proportions. The cortex is represented by cells of the epidermis (1\%), which are located in 2 layers, solid and angular collenchyme $(2 \%)$ and parenchymal cortex. As in the upper part of the stem, the bark parenchyma performs a water-saving function. These cells make up $2 \%$ of the total thickness, which is almost 8 times less than in the upper part of the same plant. In general, the bark occupies 5\%, which is 4 times less than in the upper part of the stem. Behind the bark is the cambium, which is $0,2 \%$ of the total thickness, which is 8 times less than the cambium at the top. Next is a layer of wood $(13 \%)$, represented by sclerenchyma and vascular-fibrous bundle. The powerful layer of sclerenchyme is $4,5 \%$.

The only function of the sclerenchyma is to serve as a support for the plant's organs. The distribution of this tissue in the plant depends on the loads to which the organs are subject. Since the plant is herbaceous, hidden by the primary bark-epidermis, and the water-saving parenchyma occupies a large volume relative to the entire plant, the powerful sclerenchyma layer provides the stem with a large mechanical power, which is an adaptation in the process of evolution to save a large amount of water.

Behind the sclerenchyma are vascular-fibrous bundles arranged in a circle: at the top - the phloem, followed by the xylem. They are smaller than in the upper part and make up $8,5 \%$ of the total thickness. In General, wood occupies $14,6 \%$, which is $1 \%$ more than in the upper part. The core is mainly represented by round water-saving cells. Cells of the III formation make up $6 \%$ of the total thickness, cells of the II formation $3 \%$, and cells of the I formation are not observed. The core is $36,3 \%$ of the total cut thickness, equal to half of the cut.

The lower part of the stem has a woody type of structure. The bark occupies $7,2 \%$ of the total section. It consists of a periderm and a phloem. The periderm is a secondary integumentary tissue that replaces the primary integumentary tissue-the epidermis. The periderm consists of a cork (outer layer) or phloem, which is clearly expressed on the cut, a cork cambium or phylogenies, and a pheloderme (inner layer). The periderme is $1,2 \%$ of the total thickness of the cut. Under the periderm is the primary cortex $(2,5 \%)$. Here it is represented by small homogeneous cells arranged in four layers. You should pay attention to the fact that there are no water-bearing cells in this part of the stem, unlike the upper and middle parts of this plant.

In the cortex, as already noted, there is a phloem of $13,5 \%$. In this case, there are remnants of the primary phloem (fibers and compressed thin-walled cells), and the secondary phloem is located above the cambium. Cambium 
makes up $0,8 \%$ of the total cut volume. It is followed by wood all wood in the radial direction from the core to the bark is permeated with xylem vessels. Xylem vessels have the same size. There are no I- formation vessels, and there are more II- formation vessels. They make up $0,3 \%$. Vessels of the third order are $0,6 \%$. In the wood at the core there are remnants of primary xylem. Xylem vessels are surrounded by sclerenchyma cells. As a percentage, wood occupies $17,6 \%$ of the total cut size. Behind the wood is the core $-32,8 \%$. There are no core cells in the center. So, in these plants' structure is traced the direct transition from top to bottom, from the herbaceous tuft type (upper and middle part of the stem) to the tree type structure (lower part of the stem).

The results of our research showed that the upper part of the root of Suaeda altissima $L$. has the following structure (Fig. 3): bark (6,5\%), cambium $(1,1 \%)$, wood $(89,3 \%)$, vessels $(3,1 \%)$. The bark takes up $4,7 \%$ of the total cut size. It consists of the periderm and parenchyma of the cortex. Periderme $(1,2 \%)$ consists of cork, cork cambium of phellogen and pheloderme. The cork consists of dead yellow-brown cells arranged in rows. Phellogen is represented by a layer of living thin-walled cells. The parenchyma is located along the periderme $(3,5 \%)$, whose cells are small in size. In the parenchyma of the cortex, elements of the phloem are very poorly traced. Behind the bark is cambium $-0,9 \%$ of the cut. It creates a continuous layer of living meristematic cells. Then there is the wood, which occupies most of the organ $-94,4 \%$ of the root thickness. Wood is represented here in layers. Each layer consists of a string of xylem vessels, and also gravitated to the libriform. Between the layers are cambium cells. In the upper part of the root of such layers -4 , because the reinforced mechanical part. Xylem vessels of the I formation have a size within $0,7 \%$ of the thickness of the cut, II formation $1,9 \%$, but generally prevail vessels of the III formation, almost all of the same size. The core is not observed.

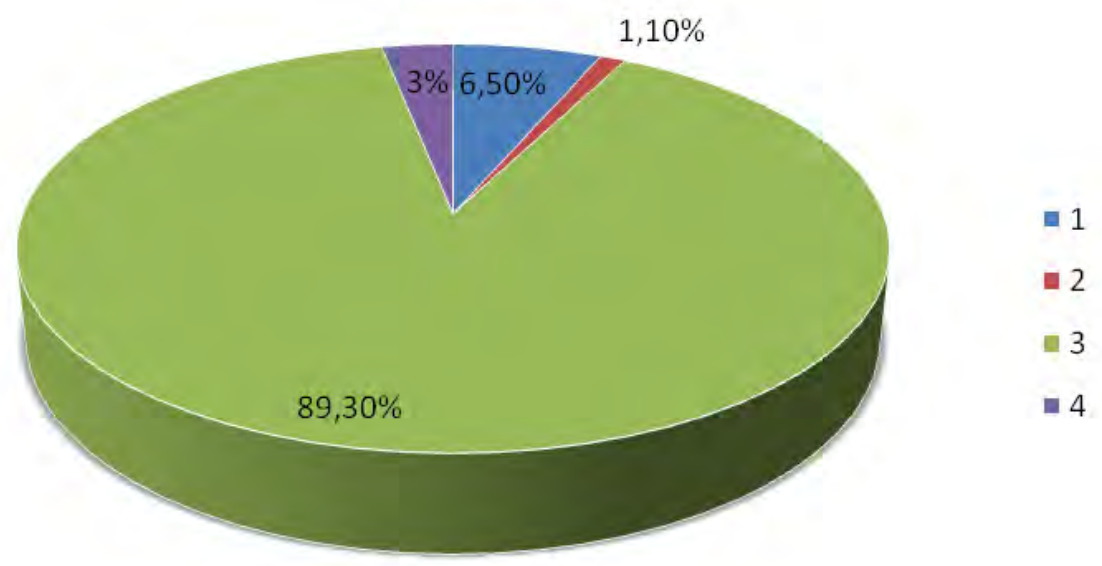

Fig. 3. Histological structure of the root of Suaeda altissima $L$. : 1-bark, 2-cambium, 3-wood, 4-vessels 
The middle part of the root consists of the same tissues as the upper and lower parts, only in different proportions. The cortex consists of the periderme $(1,2 \%)$ and the parenchyma of the cortex, which is represented by water-saving cells. The bark occupies $3,7 \%$ of the total thickness of the cut, which is $1 \%$ less than in the upper part of the root. The periderm is represented by a cork, a phelogen, and a pheloderme. The periderm cells are arranged in regular rows. On the periderm is located the parenchyma of the cortex $-2,5 \%$. The remains of the phloem can be traced in the parenchyma of the cortex. Next is the cambium $-1,3 \%$, which is more than in the upper part of the root. Wood occupies $95 \%$ and consists of layers between which there is cambium. The layer is represented by a string of xylem and libriform vessels. The wood is 7\% larger than in the upper part. There are 5 such layers in the middle part of the root. Xylem vessels of the first formation have dimensions within $0,7 \%$ of the total thickness of the cut; II formation - $1,2 \%$; III formation $-1,5 \%$. Vessels of the second order predominate. The core in this part of the plant was not detected.

The lower part of the root has the same structure as the upper and middle parts of the root, only in different proportions. The bark is represented by the periderm $(0,6 \%)$ and the parenchyma of the bark $(1,6 \%)$. In the parenchyma of the cortex, elements of the phloem are traced. After the bark is cambium $0,6 \%$, which is 2 times less than in the middle part. The main tissue of the root is wood; it occupies $97,2 \%$, which is 1,5 times more than in the middle part. At the bottom, the wood has 6 layers. Xylem vessels are mainly of the second order, their size is about $0,7 \%$, and vessels of the third order are $0,9 \%$. The size of II and III formation vessels is 1,5 times smaller than the size of II and III formation vessels of xylem in the middle part. Xylem vessels of the I formation are not observed. The core in this part of the plant was not detected. So, it is proved that the root of Suaeda altissima L. has a developed water-saving parenchyma in the cortex and mechanical tissues, which indicates the xeromorphyzation of this organ.

With the formation of the succulent stem is connected with the reduction of leaves, presents cladode. The succulent stem performs both functions: assimilation and water-saving. The epidermis, covered with a waxy coating, consists of: the main epidermal cells: uniform, transparent, tightly closed (except for the prodihovyh slits); closing cells of the prodihovogo apparatus, strongly vacuolized; stomata relatively many; external outgrowths of simple glandular trichomes ${ }^{11}$.

\footnotetext{
${ }^{11}$ Войтюк Б.Ю. Рослиність засолених грунтів Північно-Західного Причорномор'я (сучасний стан, класифікація, напрямки трансформації, охорона). Київ : Фітосоціоцентр, 2005. 224 с.

Захаревич С.Ф. К методике описания эпидермиса листа. Вестник Ленин. Университета. 1954. № 4. C. 65-75.

Казаков С.О., Пюрко О.С., Христова Т.С. Методичні аспекти фізіологічного моніторингу рослин Приазов'я. Питання біоіндикації та екології. Запоріжжя, 2002. С. 141-152.
} 
Our research showed (Fig. 4) that the shoots of Suaeda miritima L. grown in favorable conditions (control) the top covered epidermis, which consists of the following cell types: type I is 5-6 angular, rectilinear contours, angles in adjacent range - blunt projection blue, quantity per $1 \mathrm{~mm}^{2} 50-60 \mathrm{pcs}$; type II - 6 angular, rectilinear shape, the angles in adjacent boundaries blunt and direct, projection blue number of pieces per $1 \mathrm{~mm}^{2}$ is $80-90 \mathrm{pcs}$; type III -4 corner, straight contours, corners of adjacent boundaries blunt and direct, projection blue number of pieces per $1 \mathrm{~mm}^{2}-70-80 \mathrm{pcs}$.

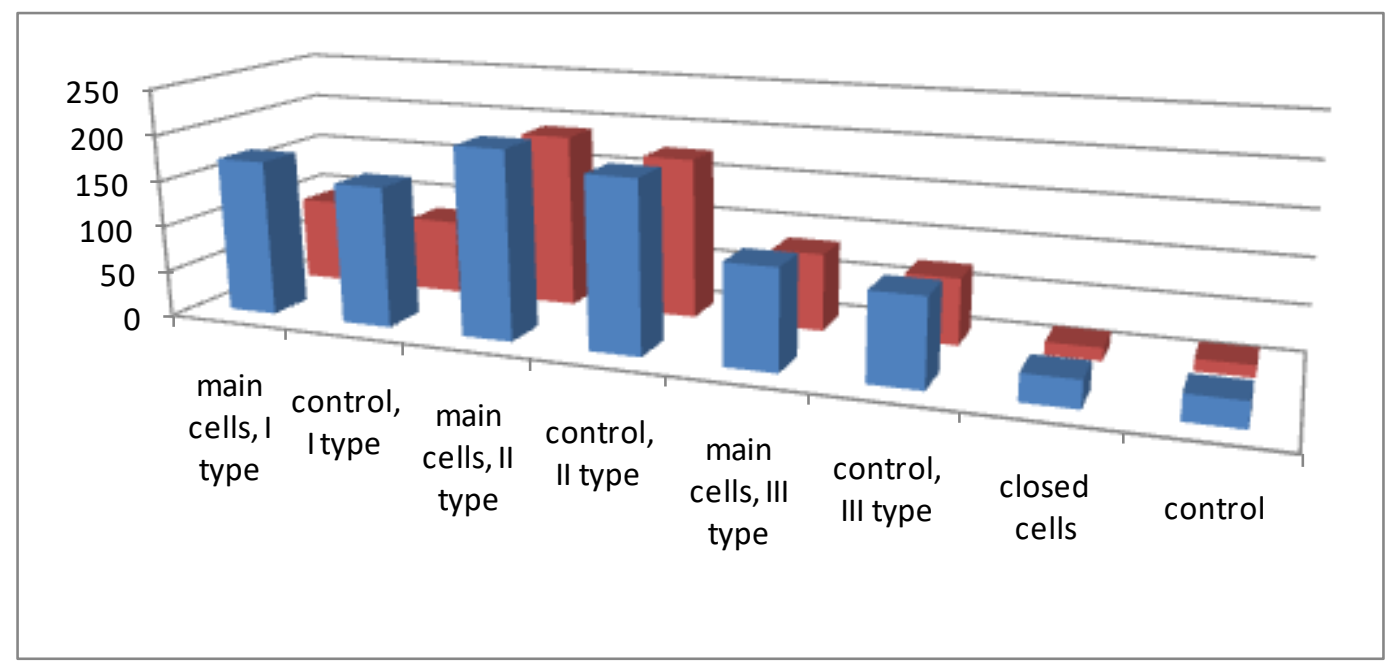

Fig. 4. Effect of salinity on the epidermis of the photosynthetic organ Suaeda miritima L.: blue color - long axis, red color - short axis

Stomatal complexes are anomositical. Salinity acts in a peculiar way on the constituent cells of the epidermis (Fig. 4), causing an increase in the size of the main cells by $12-15 \%$, and the closing ones - by $5-7 \%$. Under the epidermis is a layer of parenchyma that performs an assimilation function. Under the chlorenchyme is a double layer of water-saving parenchyme, consisting of large thin-walled cells. Closer to the chlorenchyme cells are elongated, more elongated, and closer to the stele is oval and smaller.

In the middle part of the stem, the two layers are separated by a leading system of layered imprint, which lies among the cells of the parenchyma and

Казаков Є.О. Методологічні основи постановки експерименту з фізіології рослин : монографія. Київ : Фітосоціоцентр, 2000. 285 с.

Лотова Л.И. Ботаника: Морфология и анатомия высших растений. Москва : КомКнига, 2007. 512 с.

Мусієнко М.М. Фізіологія рослин. Київ : Либідь, 2005. 807 с.

Нечитайло В.А., Кучерява Л.Ф. Ботаніка. Вищі рослини. Київ : Фітосоціоцетр, 2005. 214 с.

Bartels D., Sunkar R. Drought and salt tolerance in plants. Critical Rev. Plant Sci. 2005. P. 24-36.

Crawley M. Plant Ecology. Berlin : Blacwell Science, 2000. 717 p.

Larcher W. Physiological Plant Ecology. Berlin : Springer, 1995. 505 p.

Medvedev S.S. Plant physiology. Moscow : St-Petersburg, 2015. 506 p.

Waisel Y. Biology of halophytes. New York-London : Acad. Press, 1972. P. 146-148.

Yeo A.R. Molecular Biology of salt tolerance. Phisiol. Plantarum. 1983. V. 58. P. 214-220. 
is represented by annular vessels. When considering the structure of both the stem and root, the presence of an axial or central cylinder characteristic of these organs was noted. The pericycle in the stem is located in a narrow line in the 1-2 rows of parenchymal cells in the outer layer of the Central cylinder. The primary lateral meristem forms the lamellar colenchyme and sclerenchyme. Between the mechanical tissues and the core, 6 collateral open SVPs are symmetrically located. Between the SVP, on the edge of the sclerenchyma and the core, there is an interstitial cambium (Fig. 5).

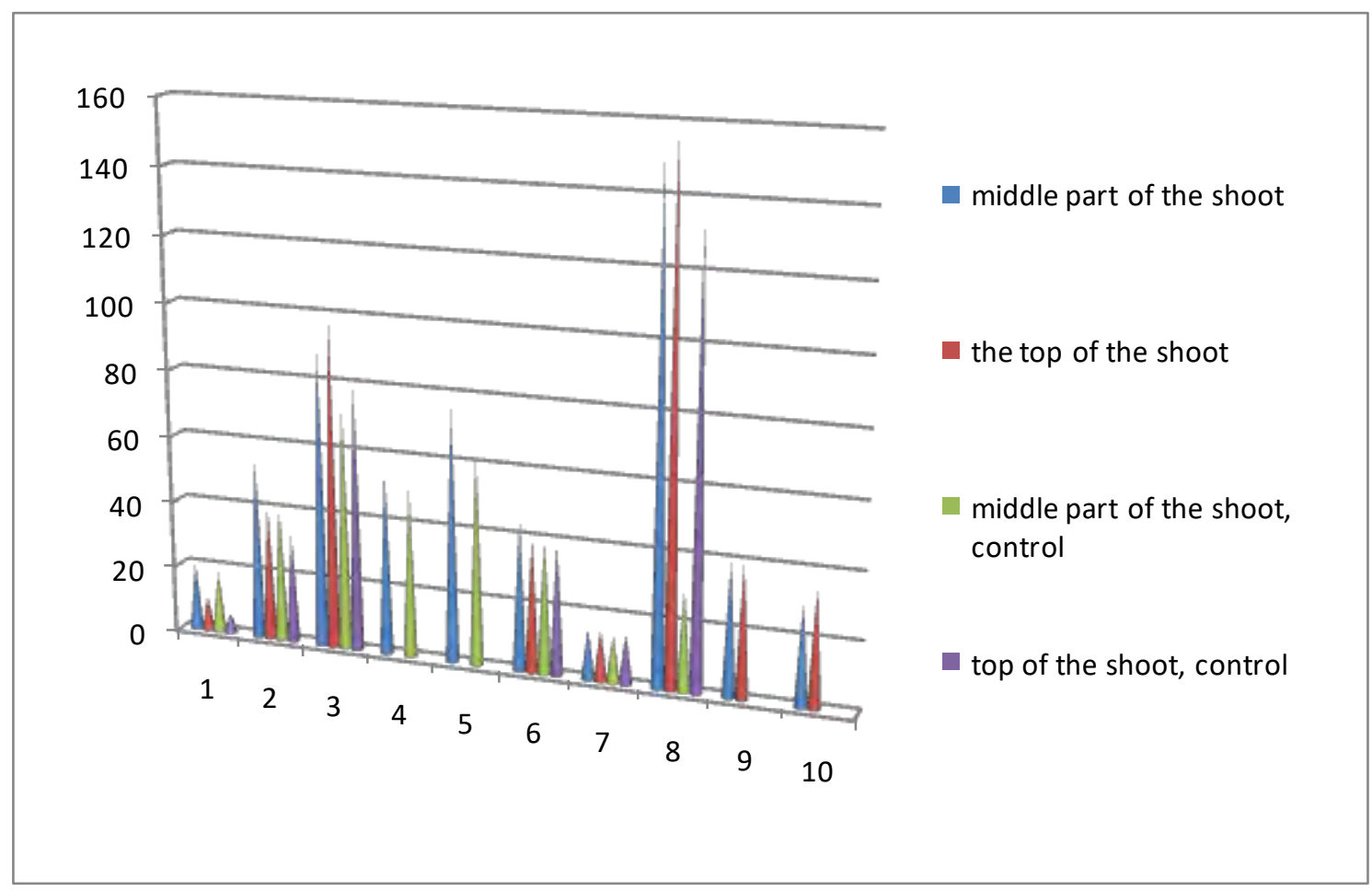

Fig. 5. Quantitative and anatomical features of shoot tissues (microns): 1-epidermis, 2-chlorenchyma, 3-water-bearing parenchyma 1, 4-leaf tracks, 5-water-bearing parenchyma 2, 6-endoderm, 7-pericycle, 8-core, 9-SVP long axis, 10-SVP short axis

Thus, the stem has austele, characteristic of most dicotyledonous plants. The endoderm is well developed, which surrounds the stele in 3-4 rows of cells. The cells are tightly closed and have thickened cells, on the entire inner surface of which the suberin is deposited. However, the endoderm does not become completely impervious to salt solutions. Substances from the crust to the stele and from the stele to the crust can only pass through the simplest, since The Caspari belts are impervious to solutions. This can be an important part of the homeostatic mechanism of physiological adaptation to salinity in evhalophytes. 
The anatomical structure of the root is characterized by a great originalitySVP are arranged in rings, alternating in the type of monocotyledonous woody plants. Due to this there is a rapid lignification and the formation of periderm, which is the adaptation to living conditions. This is a complex multi-layered tissue formed by a complex of cells: pheleme or cork (which is $54,2 \%$ ); pheleme or cork cambium (2\%); phelogen or cork parenchyma $(43.8 \%)$.

Phelema is represented by dead cells of tabular shape, gradually exfoliating, protecting from moisture loss and controlling thermoregulation, the penetration of pathogens. Phelogen - is a single layer of meristematic cells, cells of the laying tube and the outside of the cells pheloderme inside. Pheloderme performs the function of the power of phellogen. The cells of cork, pending phellogen initially have a thin shell. Then there are secondary shells consisting of alternating layers of suberin and wax. The rhizome stele is similar to an autostele. In this case, the greatest parenchymatization of the axial cylinder occurs, but the conducting beams are placed on the cross section in uneven alternating rings. There are usually about six such rings. According to this principle, in the course of work, the SVPs were divided into six orders. With each order, the number and size of SVPs increases (Fig. 6).

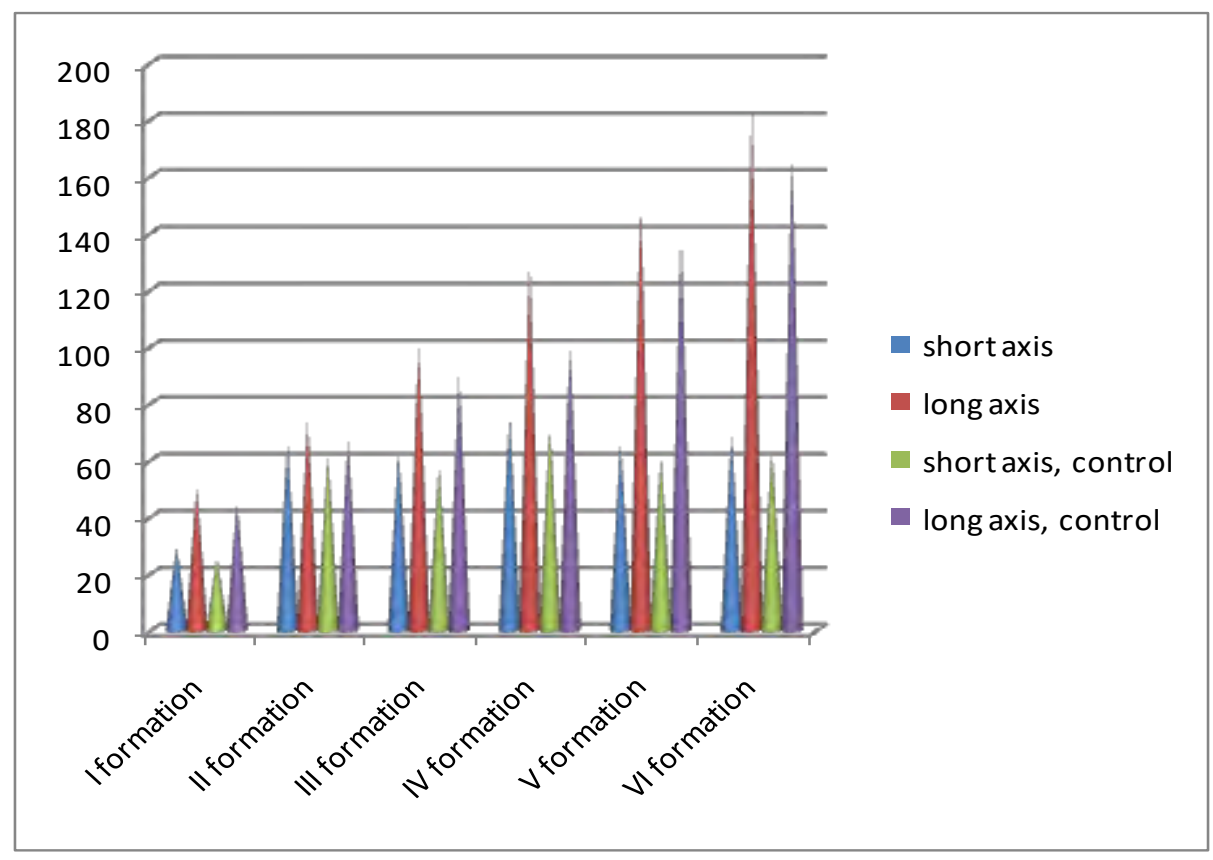

Fig. 6. Quantitative signs of rhizome SVP (microns)

The conducting beams are open and collateral. Layer between the xylem and the phloem layer is the number of cells in the cambium. In addition to the leading functions, the xylem and phloem perform a supporting and storing function. In the body of the plant, they form a continuous, closed, branched system by which all the organs and all the parts of the plant are connected. 
The composition of the xylem consists of conducting elements - the trachea, a live wheat plant's cells and mechanical fiber.

Part of the phloem consists of sieve cells, cells companion, lubyan parenchyma, lubyan fibers. Due to the meristematic activity of the cambium, open collateral vascular-fibrous bundles grow in the radial direction. Secondary tissues located closer to the cambium, and previously formed primary tissues are removed from it (Fig. 6). Therefore, the primary xylem is pushed to the primordial zone, and the primary phloem is pushed to the cortex. According to E.I. Ratner, conditions that reduce the transpiration of plants in saline soil without reducing the water content of tissues will be crucial for measures aimed at increasing the salt resistance of plants.

Our research has shown that during the day there is a closure of the stomatal apparatus in the middle of the day, which is associated with the occurrence of water scarcity. At noon, the lowest humidity and maximum temperature and light were recorded. In plants grown on saline soil, a relatively large area of the stomatal gap is observed during the day compared to the control (Fig. 7). This reduces water loss from transpiration, which is important in arid conditions.

The concentration of cell juice in plants of the genus Suaeda L. at the end of the growing season (beginning of October) is $18 \%$. Sucrose accounts for $60-70 \%$ of the amount of low-molecular water-soluble carbohydrates, which plays the role of an osmotic asset and increases the stability of plasma colloids. High osmotic pressure in the tissues - 16,46 atm., it contributes not only to a better flow of water, but also to its retention in the tissues.

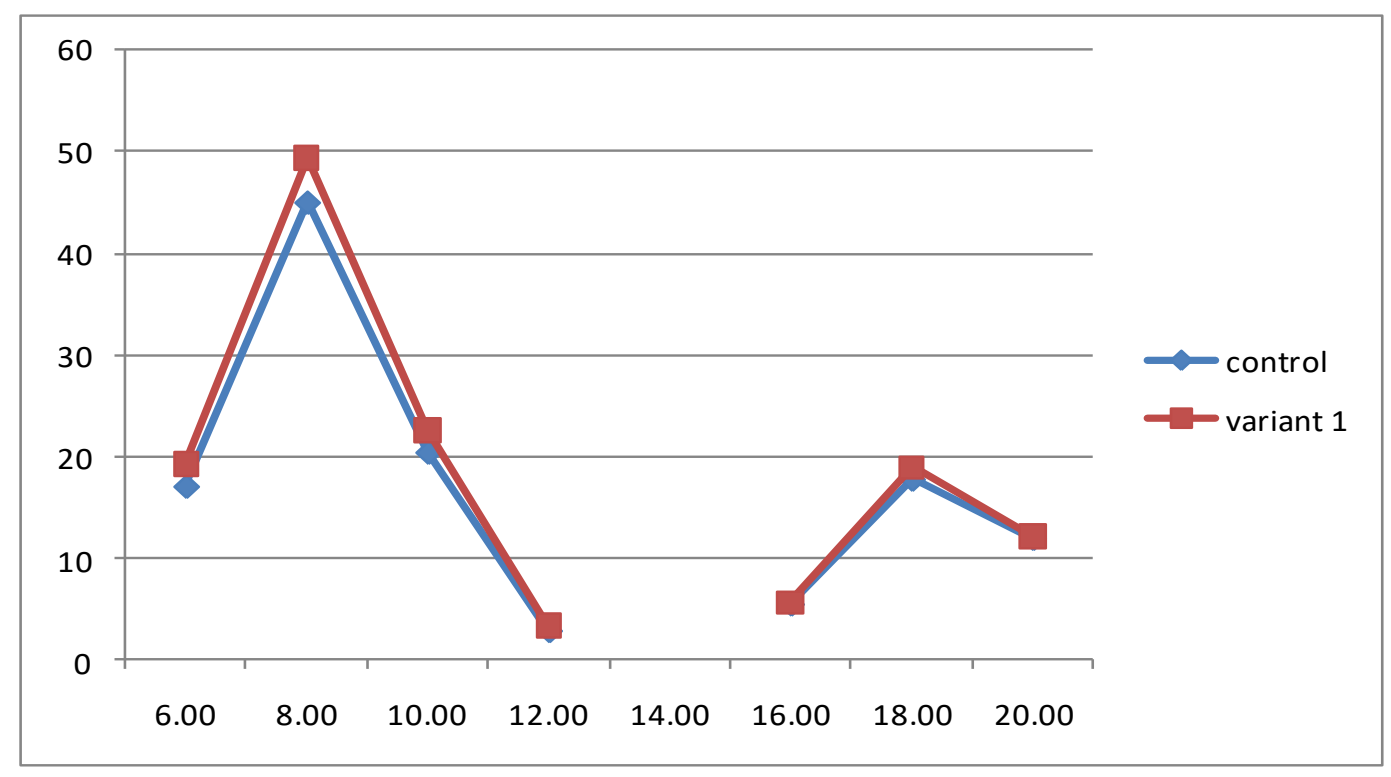

Fig. 7. Dynamics of the size of the prodihovoi gap of plants of the genus Suaeda $L$. 
The salinity of the soil in natural conditions varies greatly both in time and space and depends on the frequency of tides, salinity of water, precipitation, total evaporation, and other factors. In this regard, it draws attention to the study of the water regime in experimental, stable conditions. The minimum water content was observed in the afternoon and afternoon hours, which is associated with the highest stress of weather factors. The proportion of dry matter increases accordingly (Fig. 8).

Plants of different ecological groups contain different amounts of chlorophyll. The pigment content can be used as a biological test for plant adaptations to extreme environmental conditions.

At the end of the growing season, within a single Suaeda curtain, two forms of color of the assimilated organs can be noted: green and brown-red (Fig. 9). Chlorophyll "a" prevails in both types of plants over chlorophyll "b", which indicates the light-loving nature of the plant. A large number of carotenoids associated with their protective function, they protect photosensitive chlorophylls from photodynamic oxidative destruction of the assimilation apparatus.

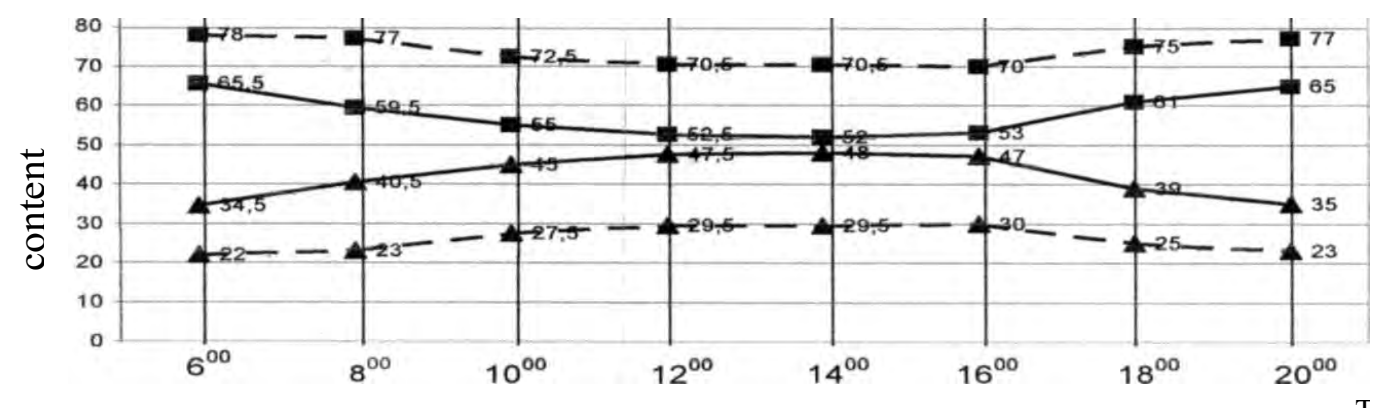

Fig. 8. Water and dry matter content during the day (option 1 - ----, control --; $\mathrm{H}_{2} \mathbf{0}-\square$, dry matter - $\Delta$ )

Differences in the color of the asymmetric shoots are due to a decrease in the number of pigments, especially chlorophylls, in the brown-red shoots. In ontogenesis, there is a gradual slowdown in the process of chlorophyll renewal, which is influenced by lighting conditions, temperature, and mineral nutrition.

Catalase effectively regulates the content of reduced oxygen forms in the cell, maintaining the necessary level of peroxidase activity, which plays an important role in determining morphogenetic processes in plant adaptation to stressful conditions. Our research has shown that catalase activity in assimilative shoots of Suaeda altissima L. is higher in plants grown on saline soil (Fig. 10).

An increase in catalase activity in plants of saline soils may indicate the accumulation of hydrogen peroxide. At noon, both during salting and in control, there is a drop in catalase activity (Fig. 11). 


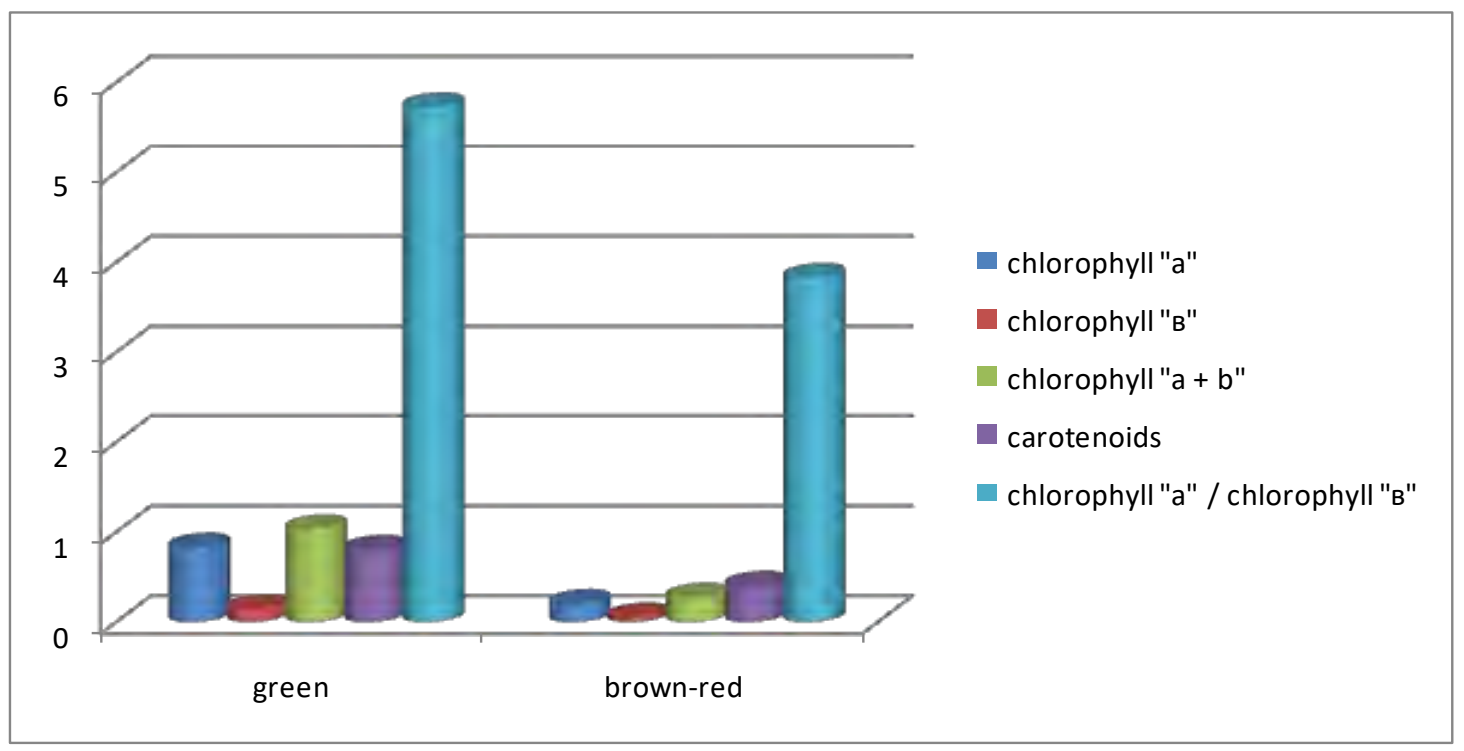

Fig. 9. Concentration of pigments in photosynthetic organs of plants of the genus Suaeda $\mathrm{L}$. $(\mathrm{mlg} / \mathrm{g})$

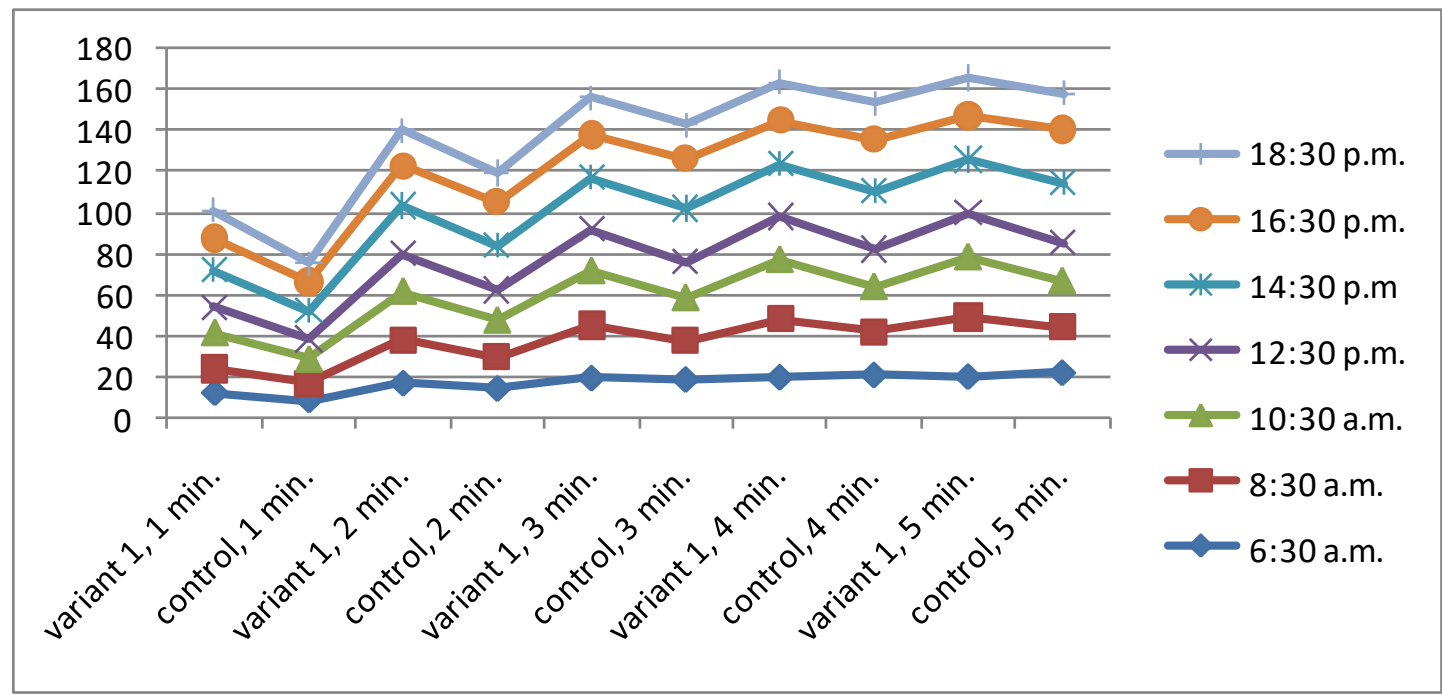

Fig. 10. Catalase activity in the assimilation organs of plants of the genus Suaeda $L$.

This may be due to water shortage or closure stomatal apparatus. Termination of gas exchange prevents photorespiration, glycolate oxidase reactions which are the main producer of hydrogen peroxide for $\mathrm{C}_{3}$-species, which includes plants of the genus Suaeda L. In ontogenesis, there is an increase in catalase activity in August-September both for plants on saline soil and for control (Fig. 12).

Thus, the maximum activity of catalase in ontogenesis is observed during the flowering phase. This is due to the intensification of metabolic processes, during which hydrogen peroxide can be formed, as well as the least resistance 628 
of plants to stress factors during this period. Minimal catalase activity is observed during the fruiting period.

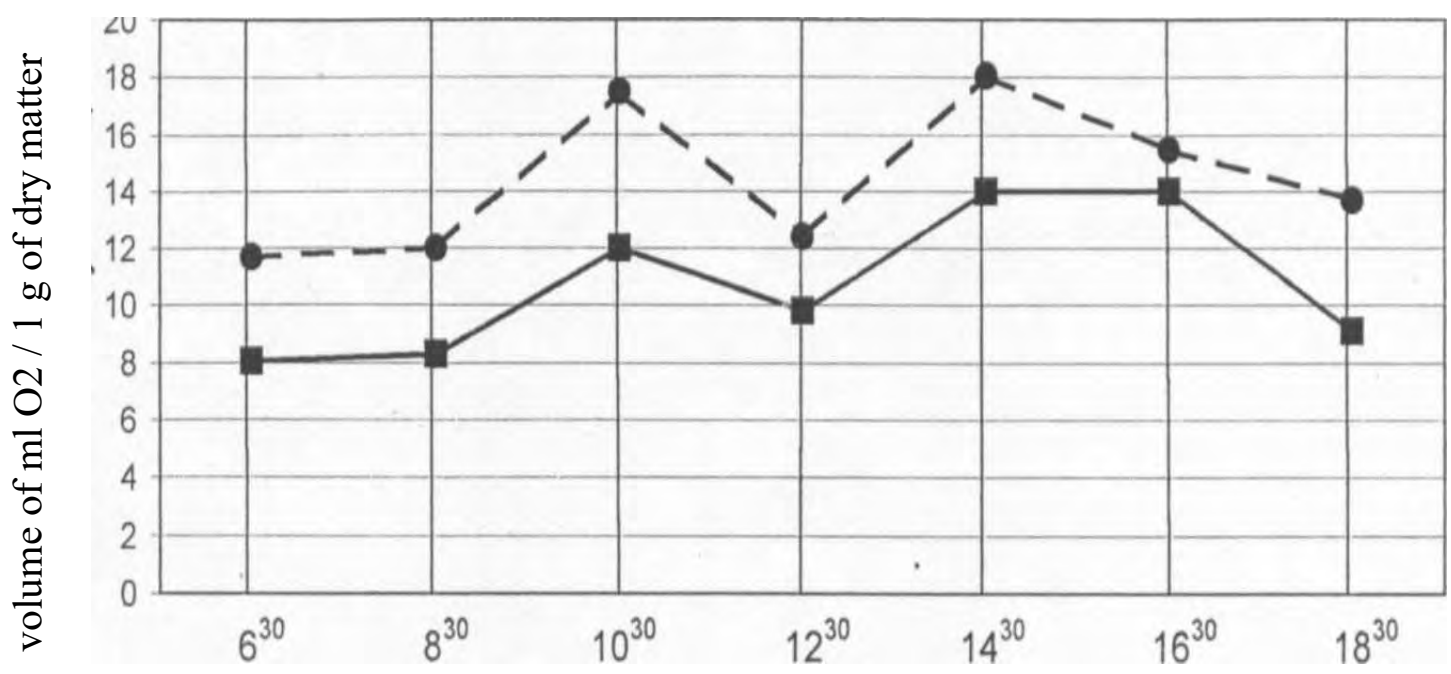

Fig. 11. Dynamics of catalase activity during the day (variant $1--$, control-)

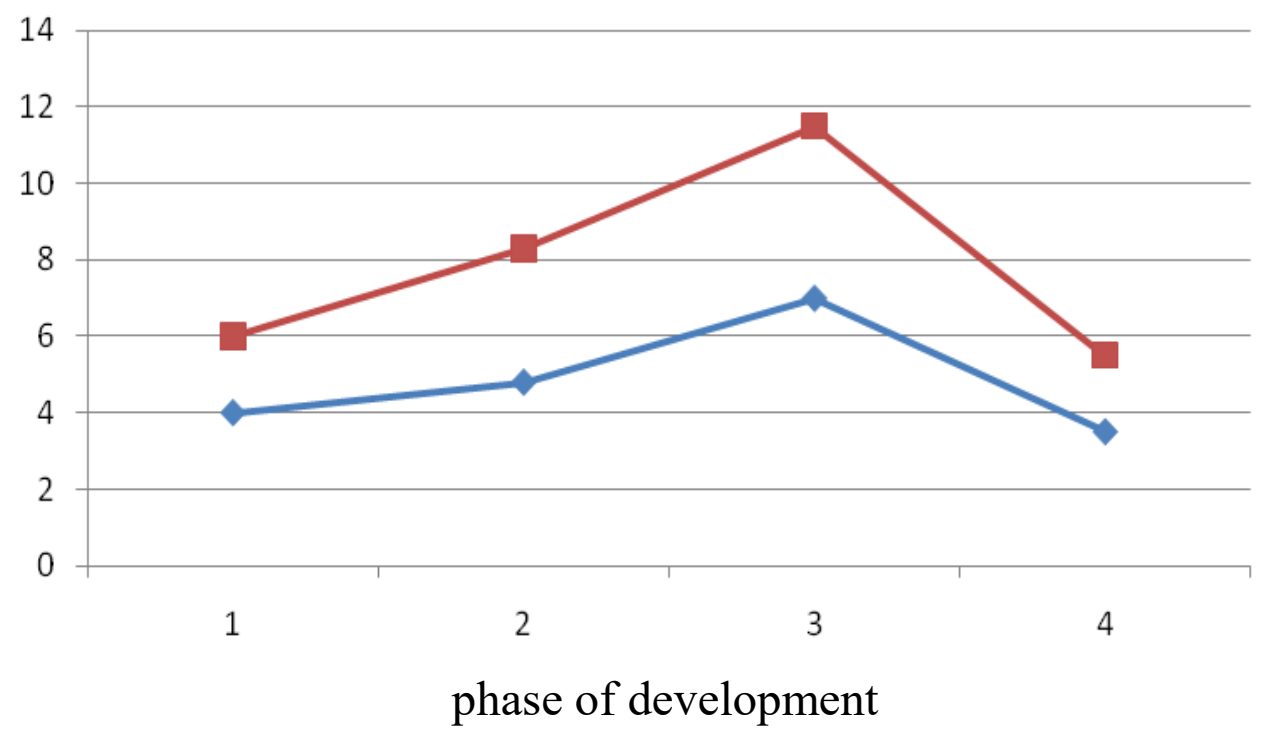

Fig. 12. Catalase activity during ontogenesis (variant 1 (red color) - -, control (blue color) -|-)

In our work, we used the "nearest neighbor" method to study competitive relationships in the cenosis. In our experiments, the distance was $2.5 \mathrm{~cm}$ (option 1), 5 (2), 10 (3), 15 (4), 20 (5). The scheme of the experiment is determined by the literature data, according to which for plants of the genus Suaeda competition in the first version will be minimal, and in the fifth almost absent. The obtained results really confirmed the strong influence of 
the growth density of plants of the genus Suaeda L. their morphometric parameters and biological productivity (Fig. 13).

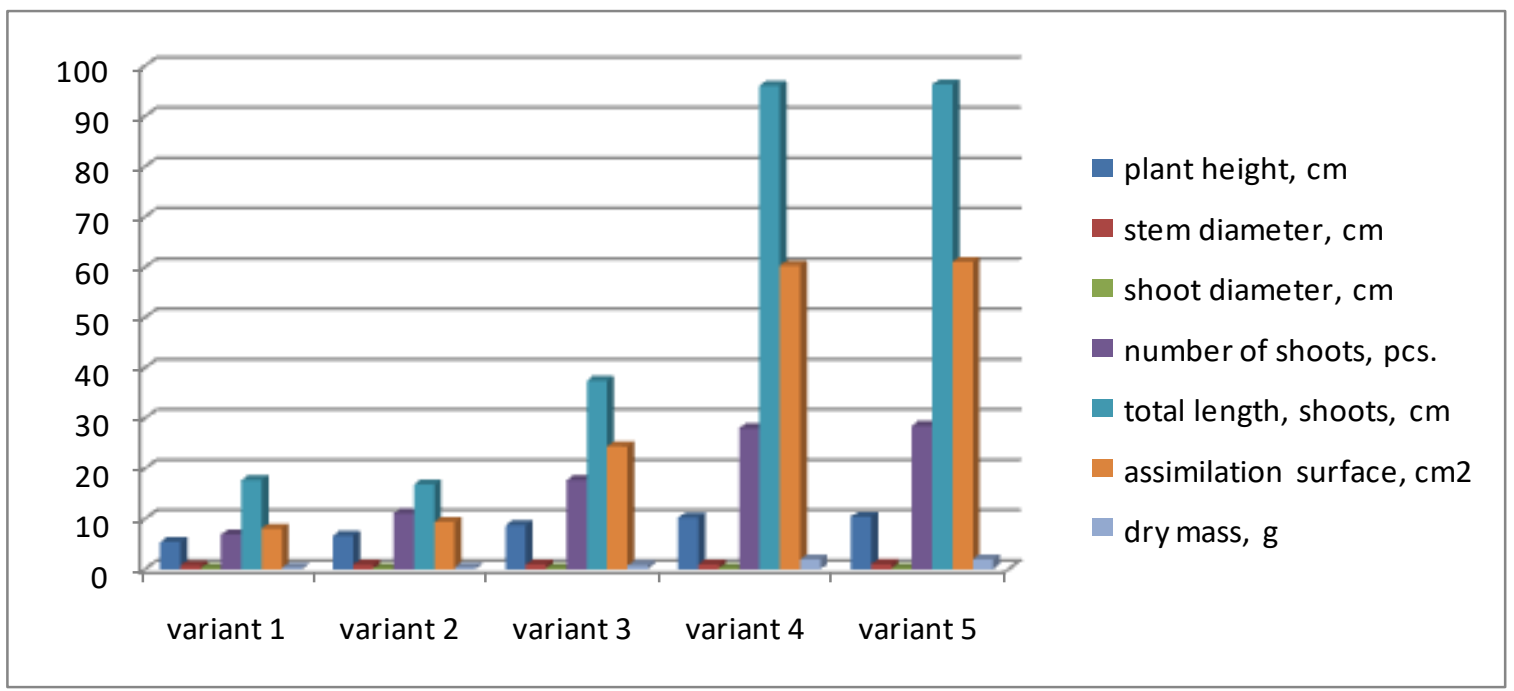

Fig. 13. Influence of growth density on morphometric indicators and productivity of the genus Suaeda $L$. plants

The obtained data allow us to state that an increase in the distance between plants by 2, 4, 6 and 8 times causes an increase in the height of plants by 1,23 (variant 2); 1,6 (3); 1,88 (4); and 1,92 (5) times, and dry weight 1,07; 2,22; 5,89 and 5,95 times, respectively. This technique stimulates branching by 4.1 times and increasing the total length of the shoot by a maximum of 5,4 times for the 5th variant. Growth features were noted which caused an increase in the assimilation surface respectively for variants b 1,2 (2); 3,0 (3); 7,5 (4); 7,6 (5) times.

In monocenoses of the genus Suaeda L. plants the intensity of competition is relatively high and depends on the distance between the nearest plants (Fig. 14).

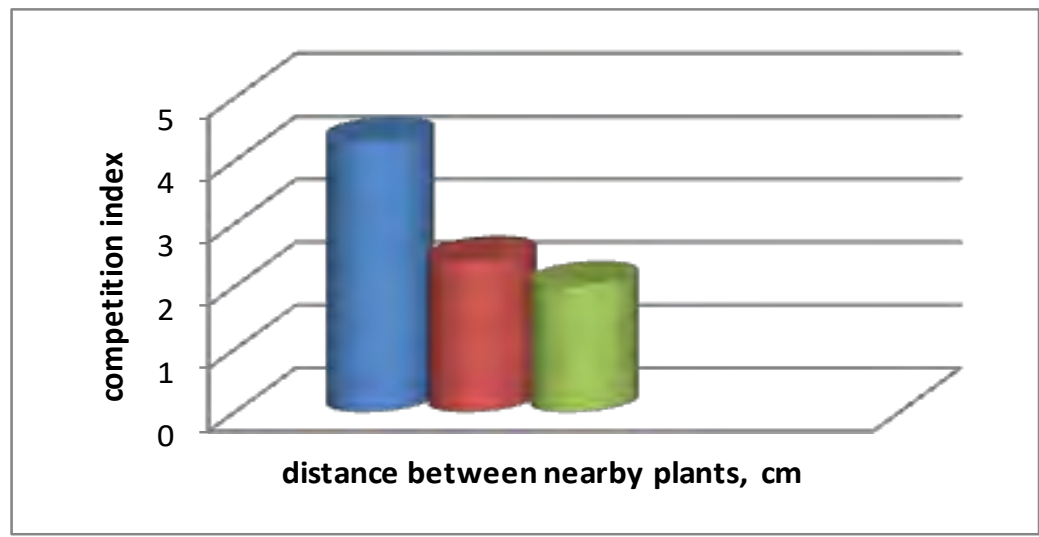

Fig. 14. relative intensity of competition in monocenoses of genus Suaeda $L$. Plants depending on the distance between plants 630 
According to the results of the above table, we can conclude that the phytogenic field of Suaeda L. ranges from 10-11 cm. In natural conditions, intraspecific competition is of great importance in monocenoses of genus Suaeda L. plants.

\section{CONCLUSIONS}

When studying the nature of the action of excess salts on plants, it is advisable to assess the suddenness, graduality and discontinuity of this action, the period of manifestation for a specific soil and climate zone. It is important to find out the histological and anatomical structures and physiological state of cells in the process of plant adaptation, the formation of their increased resistance to salt stress. Elucidation of quantitative and anatomical features of vegetative organs of Suaeda altissima L. (Pall.) showed that the longitudinal complexes of the submerged type, anomocytic. The absence of salts in the soil causes a decrease in the size of the main cells by $10-15 \%$, closing-by $5-7 \%$. Square stomata's crevices during the day more in plants grown in saline soil in comparison with the control by $8-12 \%$. Salinity causes better development of the conducting system of the stem and root. SVPs are open, collateral, and arranged in alternating rings at the root, like monocotyledonous woody plants.

Determination of quantitative and histological features of vegetative organs of Suaeda miritima L. (Pall.) proved that the stomatal complexes of Suaeda miritima L. are submerged, anomocytic. The absence of salts in the soil causes a decrease in the size of the main cells by $12-15 \%$, closing-by $7-9 \%$. Square stomata's crevices during the day more in plants grown in saline soil in comparison with control. Salinity causes better development of the conducting system by $17-18 \%$ of both the stem and root. SVPs are open, collateral, and arranged in alternating rings at the root, like monocotyledons.

The study of physiological characteristics of the genus Suaeda L. (Pall.) plants showed that the dynamics of open stomata during the day more when salinity $12-15 \%$; the concentration of cell SAP in the end of the vegetation period (beginning of October), is $18 \%$; the minimum water content was observed in the midday and afternoon hours, which is associated with the highest voltage of the meteorological factors, but this consequently increases the proportion of dry matter; chlorophyll "a" prevails in both plant species on chlorophyll "b" of 60-80\%, indicating that light kind sensibility of Suaeda $L$. (Pall.); salinization causes an increase in catalase activity by $10-12 \%$, and during ontogenesis, the greatest catalase activity is observed in the flowering phase, with tissue hydration and the volume of water-absorbing parenchyma greater by $7-9 \%$ during salinization.

Research the value of intraspecific competition in monocenoses of the genus Suaeda L. (Pall.) plants determined that the plant grows better and develops normally if the soil has the right amount of salts, which confirms the 
value of the "salt effect". Moreover, plants of the genus Suaeda L. (Pall.) require a chloride type of salinity, in which the typical halosucculentical structures are formed.

So, as a result of the influence of environmental factors on plants, in particular, such as salinity and moisture deficiency, changes the functioning, which is manifested in a wide range of fluctuations in quantitative, anatomical, functional and physiological characteristics, and in General forms the appropriate protective and adaptive responses of plant organisms to stress. Modification variability increases the adaptability of the plant organism, since the salinity of the soil in natural conditions varies greatly both in space and time. In natural conditions in monocenoses of the genus Suaeda L. (Pall.) plants intraspecific competition is of great importance.

\section{SUMMARY}

The article reveals the protective and adaptive reactions of plants of the genus Suaeda in the conditions of the North-Western Azov region of Ukraine. A quantitative and anatomical analysis of vegetative organs of the genus Suaeda L. (Rall.) plants is presented. The main cells of several types were isolated in the epidermis, which differ in size, anticlinal wall shells, projections, and the stomata apparatus of the anomocyte type. Under the influence of saline stress encountered anomalies of stomata complexes. It was found that the stem and root have a xeromorphic structure. The research expands the knowledge about the anatomical and physiological structure of halophytes and confirms that Suaeda altissima L. (Pall.) and Suaeda miritima L. belong to the real halophytes. The study of physiological characteristics of the genus Suaeda $L$. (Pall.) plants showed that the dynamics of open stomata during the day more when salinity $12-15 \%$; the concentration of cell SAP in the end of the vegetation period (beginning of October), is $18 \%$; the minimum water content was observed in the midday and afternoon hours, which is associated with the highest voltage of the meteorological factors, but this consequently increases the proportion of dry matter; chlorophyll "a" prevails in both plant species on chlorophyll "b" of $60-80 \%$, indicating that lightsensibility plants of the genus Suaeda $L$; salinization causes an increase in catalase activity by $10-12 \%$, and during ontogenesis, the greatest catalase activity is observed in the flowering phase, with tissue hydration and the volume of water-absorbing parenchyma greater by $7-9 \%$ during salinization.

\section{REFERENCES}

1. Войтюк Б.Ю. Рослинність засолених грунтів Північно-Західного Причорномор'я (сучасний стан, класифікація, напрямки трансформації, охорона). Київ : Фітосоціоцентр, 2005. 224 с. 
2. Захаревич С.Ф. К методике описания эпидермиса листа. Вестник Ленин. Университета. 1954. № 4. С. 65-75.

3. Казаков Є.О., Пюрко О.С., Христова Т.С. Методичні аспекти фізіологічного моніторингу рослин Приазов'я. Питання біоіндикації та екологіï. Запоріжжя, 2002. С. 141-152.

4. Казаков Є.О. Методологічні основи постановки експерименту 3 фізіології рослин (монографія). Київ : Фітосоціоцентр, 2000. 285 с.

5. Лотова Л.И. Ботаника: Морфология и анатомия высших растений. Москва : КомКнига, 2007. 512 с.

6. Мусієнко М.М. Фізіологія рослин. Київ : Либідь, 2005. 807 с.

7. Нечитайло В.А., Кучерява Л.Ф. Ботаніка. Вищі рослини. Київ : Фітосоціоцетр, 2005. 214 с.

8. Bartels D., Sunkar R. Drought and salt tolerance in plants. Critical Rev. Plant Sci. 2005. P. 24-36.

9. Crawley M. Plant Ecology. Berlin : Blacwell Science, 2000. 717 p.

10. Larcher W. Physiological Plant Ecology. Berlin : Springer, 1995. 505 p.

11. Medvedev S.S. Plant physiology. Moscow : St-Petersburg, 2015. 506 p.

12. Waisel Y. Biology of halophytes. New York-London : Acad. Press, 1972. P. 146-148.

13. Yeo A.R. Molecular Biology of salt tolerance. Phisiol. Plantarum. 1983. V. 58. P. 214-220.

\section{Information about authors:}

Pyurko O. E.,

Candidate of Biological Sciences,

Associate Professor at the Department of Botany and Agriculture of the Chemistry and Biology Faculty

Bogdan Khmelnitsky Melitopol State Pedagogical University 20, Hetmanska str., Melitopol, Zaporizhzhya region, 72300, Ukraine

Pyurko V. E.,

Master's in Biology and Ecology,

Physical Therapy Teacher, Teacher's Assistant Melitopol Secondary School of I-III stages № 22 of the Melitopol city Council of Zaporozhye region 32, 2 provulok Liutnevyi str., Melitopol, Zaporizhzhya region, 72304, Ukraine 